\title{
Assessment in Teaching English for Special Purpose at Tan Trao University
}

\author{
Tran Thi Thuy Lan \\ Lecturer, Department of Basic Science Faculty, Tan Trao University, Tuyen Quang, Vietnam.
}

Received date: May 10, 2021, Publication date: July 15, 2021

\begin{abstract}
As English is used more and more in professional fields and is an important communication tool at work, the teaching of English for Special Purposes at universities and colleges in Vietnam needs more and more attention. more. With the aim of improving the effectiveness of teaching and learning English for Special Purposes, this article explores the current situation of teaching English for Special Purposes at Tan Trao University, evaluates programs, materials, teaching methods and topics. Exams for English for Special Purposes courses. Through surveying students, interviewing teachers, attending teachers who are directly involved in teaching and learning English courses, and analyzing documents related to English for Special Purposes courses, research The research has pointed out the advantages and disadvantages of the English for Special Purposes courses and proposed improvement solutions to improve the training efficiency of the modules. The research results have reference value for other Vietnamese universities with the same educational background.
\end{abstract}

Keywords: English for Special Purposes, program evaluation, Vietnamese universities and colleges

\section{INTRODUCTION}

The trend of globalization with the diversification and strong development of socio-economics, science and technology has led to the strong development of English, especially specialized English. This popularity is more and more evident through the publication of more and more documents, journals, and textbooks as well as the more frequent organization of seminars and seminars on English for Special Purposes. Therefore, with the strong development of the demand for teaching and learning specialized English, the assessment in teaching English for Special Purposes is also increasingly interested and invested.

In this article, the writer wants to mention and discuss some important issues in the assessment of teaching and learning English for Special Purposes at Tan Trao University.

\section{CONTENT}

\section{Some views on English for Special Purposes}

Basically, the assessment of English for Special Purposes learners is similar to the assessment of foreign language learners in general or English in particular. We need to pay attention to the purpose of the assessment, the characteristics of the person being assessed as well as the situation in which English is used. The assessment of English for Special Purposes is aimed at reflecting learners' ability to use English for specific purposes such as English for business, tourism, engineering, etc.. The test and assessment of English for Special Purposes should be based on three basic characteristics: using contextual English, accurate specialized English language, and the interaction between English level for Special Purposes and background knowledge.

There are three common views on the assessment of English for Special Purposes teaching. Firstly, the assessment of English for Special Purposes is considered as a separate and separate part from the general trend of English assessment, which focuses on testing and measuring the English proficiency of a particular major. such as healthcare, architecture, construction, tourism, etc. Second, the assessment of English for Special Purposes is built on the basis of teaching and learning foreign languages. Accordingly, assessment helps 
DOI: $\underline{10.51386 / 25815946 / i j s m s-v 4 i 4 p 110}$

Volume: 4 Issue: 4

July to August 2021

https://www.ijsmsjournal.org

teachers understand the effectiveness and quality of teaching. Through this, we see that assessment has a close relationship with the survey of learners' needs and the design of the program or course. Third, tests and assessments are seen as tools to support learning and learning progress. The examination and examination will help learners to be aware of what has been achieved, and at the same time indicate the appropriateness of assessment and knowledge and skills to be imparted.

In principle, the English test for Special Purposes has the same basic characteristics as an ordinary English test and assessment. It should include the basic factors of validity, reliability, authenticity, interactivity, practicality, and impact. ) (Hughes, 2003). However, in fact, to assess a learner's level of English for Special Purposes, we often choose the English test for Special Purposes over the General English test due to two basic reasons: Firstly, a learner's English level varies according to different contexts, i.e. learners with certain specialties (eg: information technology, mechanics, commerce, etc.) will use English better in his or her area of expertise than in non-specialized areas. Second, the language in English for Special Purposes often has high accuracy and is more specific in each specific field.

It is important when designing a English test for Special Purposes that it should guide test takers to a combination of their English level and the area of expertise. The test for English for Special Purposes must simulate real-life situations in which learners will use English in the future.

\section{Evaluation process of teaching English for Special Purposes}

The assessment of English learners for Special Purposes needs to involve analysis input assessment, throughput assessment and output evaluation. The initial assessment is the consideration of all the factors at the beginning of the course. These factors fall into two categories: individual/student factors and organizational/school factors. Learner factors include attitudes, qualifications, experience, needs, goals, skills, etc. School factors include the structure, organization of the school (structure), equipment, goals, budget, etc.. Assessment of learner and school factors will help teachers know what learners and schools expect from them and vice versa.

According to Gimenez, the assessment of the process of teaching English for Special Purposes is often more complicated and difficult because the nature of the factors involved in this assessment process is often unstable. These factors often include learners' motivation and awareness, school context and cooperation. It is this assessment of the teaching process that will help teachers find or adjust appropriate methods and materials to help them synchronize and match the input assessment results.

While, the assessment of the output will include the analysis of the students' mid-term and final learning results. Indeed, the assessment of input and output has a close relationship because the output (ie students who complete the feeder course) is difficult to change if the input remains the same. This relationship is established through the feedback process to adjust the input properly to improve the output, which is to train students effectively. The implementation of the above assessment process, especially from the learner's side, can be carried out by means of many forms such as interviews, questionnaires, observations, student diaries, entrance tests, midterms, end of term.

\section{CONCLUSION}

The assessment of specialized English teaching needs to be according to its nature. That is, the assessment of specialized English courses or modules should follow and meet the specific and actual needs of learners. Assessing learners according to a multi-step process and involving many factors will help both teachers and learners be more active and responsible, and at the same time make the school more attentive to the needs of teachers and students. The most important thing is to help them communicate more effectively in their specialized English-using environment.

\section{ACKNOWNLEDGEMENT}

This research is funded by Tan Trao University in Yenson District, Tuyen Quang Province, Viet Nam 
DOI: $10.51386 / 25815946 / \mathrm{ijsms}-\mathrm{v} 4 \mathrm{i} 4 \mathrm{p} 110$

Volume: 4 Issue: 4

July to August 2021

https://www.ijsmsjournal.org

\section{REFERENCES}

[1] Dudley-Evan, T. \& St John, M. T. (1998). Developmentin ESP. Cambridge: Cambridge University Press.

[2] Douglas, D (2013). ESP and Assessment. In B, Paltridge, \& S, Starfield (Eds), The Handbook of English for Specific Purposes Wiley-Blackwell.

[3] Douglas, D (2000). Assessing Languages for Specific Purposes. CambridgeUniversity Press.

[4] Dudley-Evans, T \& St. John, M (1998). Developments in English for SpecificPurposes. Cambridge University Press.

[5] Guyot, W.M. (1978). Summative and FormativeEvaluation. The Journal of Business Education,54(3), 127-129.

[6] Gimenez, J (1996). Process Assessment in ESP: Input, Throughput and Output.English for Specific Purposes, 15 (3), $233-241$ 